\title{
Jihadism: What is a Terror Apparatus? Interview with Jacob Rogozinski
}

\author{
Jacob Rogozinski, ${ }^{1}$ Andreas Wilmes ${ }^{2}$ \\ ${ }^{1}$ University of Strasbourg, France \\ ${ }^{2}$ University Paris Descartes, Centre de Recherches sur les Liens Sociaux (CERLIS)
}

\begin{abstract}
In the present interview, Jacob Rogozinski elucidates the main concepts and theses he developed in his latest book dedicated to the issue of modern jihadism. On this occasion, he explains his disagreements with other philosophical (Badiou, Baudrillard, Žižek) and anthropological (Girard) accounts of Islamic terrorism. Rogozinski also explains that although jihadism betrays Islam, it nonetheless has everything to do with Islam. Eventually, he describes his own philosophical journey which led him from a phenomenological study of the ego and the flesh to the study of past (witchhunts, French Reign of Terror) and contemporary (jihadism) terror apparatuses.
\end{abstract}

\section{Keywords}

Alain Badiou; Jean Baudrillard; Jacques Derrida; Michel Foucault; René Girard; jihadism; witch-hunt; sacrifice; Terror apparatus.

PJCV: Jacob Rogozinski, your latest book introduces a new philosophical analysis of jihadism. Philosophers like Derrida, Baudrillard, Badiou, and Žižek, to name just a few, already tried to understand this phenomenon. What distinguishes your approach from theirs? Have you been discontent with the philosophical essays published in the aftermath of 9/11 and after the most recent attacks in France and Europe? Was this your main reason for writing this book?

Jacob Rogozinski: The recent terror attacks in France and Europe prompted me to write this book. I have to say that I was not content with the analyses made by those philosophers. It seems to me that most of them approached the phenomenon of jihadism by insufficiently considering its religious references, that is to say, its rooting in Islam. When Badiou defines jihadism as a kind of "fascistic nihilism," he his wrong in two respects: first,

\footnotetext{
1 See Alain Badiou, "Philosophy and the 'war against terrorism", in Infinite Thought (New York: Continuum), 141-163. For the philosophical critique of Badiou's theses see Jacob Rogozinski,

This is an Open Access article distributed in accordance with the Creative Commons Attribution Non Commercial (CC-BY-NC-ND 4.0) license, which permits others to copy or share the article, provided original work is properly cited and that this is not done for commercial purposes. Users may not remix, transform, or build upon the material and may not distribute the modified material (bttp:/ / creativecommons.org/ licenses/by-nc/4.0/)
} 
by equating a new phenomenon to an old and different one (fascism) and, secondly, by claiming that we are dealing with people who no longer believe in anything. Since Nietzsche, this is indeed the definition of "nihilism." Can we really name nihilists men who are willing to kill and die in the name of their beliefs? Badiou only sees in the religious dimension of jihadism a superficial "disguise," that is to say, a mask that would conceal a deeper reality. What kind of reality? The "desire for the West" and the ravages of global capitalism. In the same vein, Žižek states that the violence of fundamentalists is just one of the forms of violence related to global capitalism. ${ }^{2}$ Baudrillard said the same thing in a more sophisticated way by calling terrorism "the shadow" of the "system of domination," its internal "counterapparatus." 3 All those statements amount to ignore the peculiarity of modern jihadism. Ultimately, such stances can lead to excuse jihadists of their crimes by merely seeing them as victims of global capitalism. This trend is present in some far-left circles. These people believe that "victims," whatever they do, are always right. They do not see that when people revolt against the system which is oppressing them, their revolt may be misguided, captured by what I call terror apparatuses [dispositifs de terreur].

Starting from the $18^{\text {th }}$ century, Western intellectuals tend to perceive religion as an inconsistent illusion, an "ideology," a mystification which has to be cleared-up. They cannot take into account the truth nucleus of religion to which Freud refers to. In understating the religious dimension of jihadism, the philosophers that you just mentioned make the same mistake. The exception is Derrida who took the issue of religion seriously. His analysis of the "return of the religious" as a "self-destructive" and "auto-immune"4 affirmation of religion was very useful for me to understand what is at stake in Muslim fundamentalism. But Derrida's work stops right before the threshold of what has to be thought today: how is it that this reaffirmation of the religious takes place in the Islamic world in a (self)destructive form which is much more virulent and more fanatical than in other religions? To understand this phenomenon, I went back through the history of Islam and tried to identify what, in this religion, could give rise to the jihadist terror apparatus. We are wrong and naïve when we state that jihadism has "nothing to do" with Islam. But it is equally wrong when some claim that jihadist terror would show the essence of Islam - and, ultimately, the fundamentally-intolerant and fanatical features of every religion. This idea is defended by an ever-increasing number of intellectuals and media personalities in France. This stance risks "demonizing" Islam by perceiving it as a flawless bloc, completely hostile to the West, to democracy, to modernity. On the contrary, we need to find the features opposing fundamentalist interpretations in the classic Islamic tradition as well as in its founding texts. We need to find these points of resistance which I call the lost treasures of Islam [trésors perdus de l'islam]. In rediscovering them, Muslims might be able to resist the deadly attraction of fundamentalism and jihadism.

Djihadisme: Le Retour du Sacrifice (Paris: Desclée de Brouwer, 2017), 22-23. See also Jacob Rogozinski, « Le philosophe et le djihadiste », Le Monde (February 20, 2015),

http://www.lemonde.fr/idees/article/2015/02/20/le-philosophe-et-le-djihadiste_4580674_3232.html (accessed October 5, 2017).

2 Slavoj Žižek, Against the Double Blackmail (London: Penguin Books, 2016).

${ }^{3}$ Jean Baudrillard, The Spirit of Terrorism (London: Verso, 2002), 10.

${ }^{4}$ Jacques Derrida, Acts of Religion (New York: Routledge, 2002), 78. 
PJCV: As a matter of fact, you intend to bypass our current debates which demand us to choose between the negation of religion or its demonization. In your book, you state that, similarly to Judaism and Christianity, Islam implies a "project of emancipation"5 ["projet émancipateur"] which could, in particular, be seen in the Quranic "criticism" of "political idolatry." Historical events often betray this project of emancipation - as in the case of jihadism in which the hatred of the enemy goes beyond any ideal of justice. Now, at this point, how is it possible to avoid the pitfalls of the negation or the demonization of religion? Because some might consider the jihadists' betrayal of the emancipatory project as an issue which is alien to religion. And other persons might think that the issue is the religious and emancipatory project in itself: either because it conceals a certain resentment, or because it fails to properly articulate the temporal with the spiritual...

Jacob Rogozinski: What you call the "negation" of religion may very well correspond to its "demonization." This is a very common stance among Western intellectuals. On the one hand, it is said that religion is only an inconsistent illusion - an alienation, an ideology, a neurosis - which will soon be cleared-up thanks to the progress of Science and Reason. On the other hand, there are worries about the persistence or "return" of this illusion and it is then denounced as an "obscurantist" and incomprehensible regression. Either way, there is a refusal to enquire the fundamental meaning of religion, or rather of the different phenomena that we quite arbitrarily group under this label. It would be better to renounce this too massive and static concept of "religion" and to discuss instead "apparatuses of belief". Those are heterogeneous networks, traversed by fractures and lines of flight, which are constantly changing and are subject to radical changes. Among these apparatuses, most are, in Max Weber's words, means "of legitimizing domination and the domestication of the dominated." But some of them operate quite differently: as counter-apparatuses or apparatuses of emancipation supporting the resistance of the oppressed. This is the case of these apparatuses of belief which are Judaism, Christianity, and Islam. Their starting point is the legendary account of the Exodus telling how slaves threatened with extermination managed to free themselves from the "house of bondage" under the leadership of a charismatic leader capable to confront the pharaoh. The founding event of Islam is also an exodus through the desert which mimetically repeats the legend of Moses. The critique of idolatry and the prohibition of worshiping images are first and foremost political: as the Egyptologist Jan Assmann reminds us, ${ }^{7}$ the power of the pharaohs was sacred, and they were venerated as "images of the gods." It is the same sacralisation of power of emperors that nascent Christianity will oppose, and the Quran will also denounce the sovereigns' pretence to be worshiped as gods. To me, this critique of political idolatry still seems up to date. Just think of how totalitarian leaders like Hitler, Stalin, or Mao have been idolized, almost deified by their followers. In the Abrahamic apparatuses of belief, the refusal to sacralise political power is founded on a condition of equality between men who are all children of Adam and equal before God. It is often said that Ancient Greece has been the birthplace

\footnotetext{
${ }^{5}$ Jacob Rogozinski, Djibadisme : Le Retour du Sacrifice, 127.

${ }^{6}$ Ibid., 134.

${ }^{7}$ See for instance Jan Assmann, Of God and Gods: Egypt, Israel and the Rise of Monotheism (Madison:

University of Wisconsin Press, 2008).
} 
of democracy, but we forget this other source of modern democracy, namely the legacy of the Exodus and this first "Republic of the Hebrews" which Spinoza praised, this politicalreligious utopia which also persists in Christian and Muslim traditions. Derrida saw it well enough when he wrote that "the modern figure of the democratic state" is "more Abrahamic than Greek in its essence." 8 Admittedly, we know that the project of emancipation of the Abrahamic religions has been betrayed and abandoned and that it failed each time, just as the revolutionary movements of modern times will later fail. Each time, an apparatus of domination was rebuilt and the apparatus of belief was used for its legitimization. This is not enough to renounce the prospect of human emancipation. Socially dominant people, for whom such a perspective is unbearable, accuse these movements of being solely motivated by "resentment." On the contrary, anger, revolt, and hope are positive and creative affects as long as they guide men towards a condition of equality, that is to say, towards an Idea of justice. This is obviously not the case with terror apparatuses such as jihadism, which are driven by the worst negative passions: hatred.

You ask me a formidable question, that of the articulation between the "temporal" and the "spiritual" - I would rather say: the articulation between apparatuses of power and apparatuses of belief. Historical experience shows that no movement of emancipation could do without some imaginary identification with heroes or sacred figures. These political counter-apparatuses always needed to rely on counter-apparatuses of belief which have sometimes taken the form of secular religions, such as the cult of the Supreme Being during the French Revolution. Is it the cause of their failures? I am not sure. On the contrary, one might think that these two dimensions are inseparable and that there can be no struggle for emancipation without a share of messianic hope. If this is the case, it should be concluded that the "disenchantment of the world," that is to say, the general disbelief that we are witnessing, is an obstacle to any project of emancipation. But can we conceive a human society entirely devoid of beliefs? Can a community persist without its symbolic marks of belonging, without collective poles of identification, and could they take a form which would not be religious? I admit that I have no answer to these questions.

PJCV: The notion of "apparatus" already plays a key role in your previous book devoted to the issue of Witch-Hunting. ${ }^{9}$ Although you borrow this notion from Foucault, you point out that the apparatuses of power (not to be confused with the apparatuses of belief that you just mentioned) are not only about exclusion or normalization: one must acknowledge the existence of apparatuses of terror and persecution. What are your methodologies for describing those apparatuses?

Jacob Rogozinki: I think that philosophy should not be limited to commenting on the texts of its own tradition and that it should open itself to the life of men, and especially of these "infamous men" mentioned by Foucault: these "lowly-lives reduced to ashes,"10

\footnotetext{
${ }^{8}$ Jacques Derrida, The Gift of Death \& Literature in Secret (Chicago: University of Chicago Press, 2008): 110.

${ }^{9}$ Jacob Rogozinski, Ils m'ont haï sans raison : de la chasse aux sorcières à la Terreur (Paris : Editions du Cerf, 2015).

${ }^{10}$ Michel Foucault, Power, Truth, Strategy (Sidney University: Feral Publications, 1979), 77.
} 
ignored by official history devoid of pheme - of reputation - and whose existence simply left a trace in archives "at the point of their instantaneous contact with power."11 I aimed to understand the logic of hatred, this affect which I already analysed from a phenomenological point of view in The Ego and the Flesh. ${ }^{12}$ A purely conceptual analysis did not seem sufficient to me and I decided to direct my researches towards history. My aim was to understand how hatred occurred in a historical phenomenon of persecution, such as the Great Witch Hunt which killed hundreds of thousands of people from the $15^{\text {th }}$ to the $17^{\text {th }}$ century. So, I used the materials of the historians who made us aware of this persecution - above all, the admirable works of Michelet and Carlo Ginzburg. Thanks to them, it was possible for me to listen to the muffled voices of those men and women who had been silenced, tortured, murdered. I had to develop new concepts, in particular the concept of apparatus of persecution or terror apparatus. They are apparatuses in a Foucauldian sense, but they are different from the apparatuses of exclusion and normalization that he analysed in Madness and Civilization and in Discipline and Punish. The purpose of those apparatuses is not to confine, expel or "discipline" the men they target, but to annihilate them. I wanted to understand how apparatuses of persecution can capture the affects of the masses to use them as means for their own strategies. The turning point which made the capture of affects possible are certain intermediate representations that I decided to call schemas. This is a concept that I borrowed from Kant but I gave it a slightly different meaning which is more "practical" and not just theoretical. This enabled me to understand another phenomenon that Foucault did not thoroughly examine. He did not see that apparatuses could sometimes mutate and turn into apparatuses of another type. In that respect, the apparatus of exclusion and confinement of the lepers later turned into an apparatus of persecution. All of a sudden, in 1320, in the south-west of France, lepers were accused of "conspiring" with the Jews against Christians. Immediately, furious crowds invade the leprosariums, then the ghettos by massacring their inhabitants, and the persecution quickly spreads to the whole kingdom. How can we account for this shift from exclusion to persecution? Among the schemas that are at work in witch hunt, and already in the persecution of lepers and Jews in the Middle Ages, the schema of the conspiracy plays a decisive role. Each time, these different targets are accused of being part of a "conspiracy" that attempts to ruin the authority of the Church and the state in order to seize power. From then, it is no longer sufficient to exclude them through confinement into ghettos or leprosariums: the mere fact of their existence becomes a threat and they must be exterminated. This schema of persecution is both persistent and flexible: it runs through centuries by changing its targets and adapting itself to new historical contexts. And even if it sometimes seems that this schema disappears, it is each time reactivated and reappears in new forms. A few years ago, who would have thought that the old myth of the evil "conspiracy" would reappear at the beginning of the $21^{\text {st }}$ century and spread so massively on the Internet? And yet, however persistent they may be, such schemas are not timeless archetypes: they were made in the course of history and we might hope, after important

\footnotetext{
${ }^{11}$ Ibid., 80.

${ }^{12}$ Jacob Rogozinski, The Ego and the Flesh, trans. Robert Vallier (Palo Alto: Stanford University Press, 2010).
} 
social transformations and a long and patient work of criticism and education, that they will eventually disappear one day.

I must say that I would never have engaged in this witch-hunt research if I had not sought for years to understand another, even deadlier, persecution: The Holocaust. I never managed to understand it before, probably because this event concerned me too directly in my family history. In choosing a more historically distant persecution phenomenon as a research topic, I have come to understand the logic of hatred and how it can, by means of certain schemas, engage itself into apparatuses of persecution and terror.

PJCV: You define the schema as an "imaginary representation charged with affects"13 ["representation imaginaire investie d'affects"]. According to you, it is naïve to suppose that the apparatus of jihadist terror could be reducible to the founding text of the Quran. Jihadism needs to "mobilize the desires and passions of men"14 ["mobiliser les désirs et les passions des hommes"] through schemas. By the same token, you state that the psychiatrization of jihadism (which equates the phenomenon with a form of modern nihilism) tends to ignore the politico-religious dimension of those schemas. Jihadism is not only motivated by the hope of "dying to be reborn"15 ["mourir pour renaître"], but also by apocalyptic and messianic concerns such as the ultimate battle of Dabiq, the confrontation with the evil figure of Al-Masih ad-Daijal and the coming of the Madhi (i.e. the eschatological redeemer of Islam). Could you expand on this and tell us what makes those schemas attractive to some people today?

Jacob Rogozinski: Although they persist through centuries, schemas appear in history and they are not static: they change by dissociating themselves into several distinct or even opposite schemas or, on the contrary, by associating - sometimes even merging themselves with other schemas. Since they are flexible, they can be incorporated into very different apparatuses of power or belief. In the Torah, the name "messiah" designates the Lord's anointed, that is to say the one who received the sacred anointing and thus became endowed with a divine mission. At first, this schema is completely different from the representation of an end of times. It is only later that it tends to merge with the schema of the apocalypse. Then, it incorporates a series of representations that will become inseparable from him such as the announcement of a final battle between Good and Evil and of the destruction of our world and the birth of a new one: a Kingdom of justice where evil will have vanished. At about the same time, at the beginning of the Christian era, this schema divides itself into two antagonistic figures, now opposing the divine Messiah and a satanic anti-messiah whom the Christians call the Antichrist and the Muslims the Daijal (the Imposter). It is in this form that the messianic schema will cross the entire western history. It underlies the millenarian uprisings of the Middle Ages and the Renaissance. Then, it will lose its initial religious dimension, and one can find it later in modern times in the emancipatory movements and the "secular religions" they generate. The revolutionary class

\footnotetext{
${ }_{13}^{13}$ Jacob Rogozinski, Djibadisme : Le Retour du Sacrifice, 58.

${ }^{14}$ Ibid., 59.

15 Ibid., 61.
} 
which Marx calls the proletariat has a Messianic dimension, and the Communist Revolution manifests itself in this new belief as a transposition of the Christian Apocalypse. Each time, this schema captures an affect which motivates all revolts: hope. This schema can also associate hope with other affects which are apparently very different. In that respect, hope in the coming of the Messiah and an intense hatred towards the anti-messiah and his henchmen can go hand in hand, and they can actively support apparatuses of persecution and terror. The same schema can be found in the tradition of Islam. Even today, many Muslims continue to await the arrival of the Mabdi, the Messianic Saviour, and his victorious fight against the Dajjal. According to the tradition, this battle will take place in Dabiq, in northern Syria, and will be the prelude to the final judgement. In my opinion, it is impossible to understand jihadism and its attraction for certain Muslims without taking into account its messianic and apocalyptic dimension. It is no coincidence that one of Daesh's magazines is entitled Dabiq, and that this movement favoured the technique of suicideattack. When a jihadist fighter blows himself up to kill men whom the apparatus points out as enemies, he hopes to "die as a martyr" and reach eternal life. On the individual as well as on the collective level, it is a question of dying to be reborn. This schema is so conspicuously present in Daesh's strategy that it gives it an oddly suicidal and self-destructive appearance. I do think that the belief in the resurrection is not a mere illusion. It is rooted in a primordial phantasm whose origin lies in the life of our Self and which appears in different ways in individual and collective existence (I aimed at describing the genesis of this phantasm in The Ego and the Flesh).

PJCV: You mention Benoit Chantre in the acknowledgements of your book. In the paper he wrote for our dossier on jihadism, ${ }^{16}$ Chantre frequently defends ideas very similar to yours such as the critique of the theories of the "end of religion," the refusal to reduce jihadism to a "nihilism in a religious guise" and the hypothesis of a return of archaic violence within Islam. But Chantre draws his conclusion starting from a different framework: René Girard's mimetic theory. Could we say that your two perspectives imply comparable results while resting on two rather different conceptions of sacrifice? Your approach of the issue of sacrifice reminds me more of Freud and of some of Joseph de Maistre's intuitions than Girard's mimetic theory...

Jacob Rogozinski: I would probably never have written this book without Benoit Chantre's friendly insistence. We worked closely together on this book and, as you mentioned, our stances on the issue of jihadism are often similar. I have a lot of admiration for René Girard's mimetic theory, even if, according to me, some of its aspects need to be amended and supplemented. In this respect, his concept of "violence" seems too abstract and undifferentiated to me. There are several types of violence implemented by different apparatuses, and Girard is wrong by only taking into account the most extreme violence murder - and by ignoring the more subtle, insidious forms of violence which are exclusion or normalization and discipline. It also seems to me that he was not interested enough in

\footnotetext{
${ }^{16}$ Benoit Chantre, "Terrorism and Democracy", The Philosophical Journal of Conflict and Violence $1 / 2$ (2017).
} 
the sublimation and symbolization processes which are at work in the apparatuses of belief. This is why he tends to reject most religions - with the exception of Christianity and, to some extent, Judaism - and situates them on the side of archaic sacredness and sacrificial violence. But the main limitation of his theory is that its scope is restricted to the sole plane of collective phenomena. The "mimetic rivalry" which is the cornerstone of his anthropology already supposes two, or rather three, individuals. On the contrary, I think that the phenomena which appear on this plane are rooted in a more originary dimension, that is to say in the relation of each singular Self to its own Flesh - or, more exactly, to a part of his Flesh, to a "remainder" [restant] that he must either incorporate or reject outside of him. This expulsion of the "remainder" is re-enacted on the collective level in various practices, rites and symbols. The retrenchment and transfiguration of this heterogeneous element is staged in sacrificial rituals. The "cuisine of sacrifice" always consists in extracting from the dismembered body of the victim a share reserved for the gods or for God. It is a human or animal victim distinct from the sacrificer, but to whom he identifies. Sacrificial rites originate in an auto-sacrifice: it is a part of our Flesh and of our Self which has to be expelled and destroyed. At the same time, this part of the Flesh will be purified and sacralised in order to offer it to a deity. As shown by the founding myth of the three Abrahamic religions (i.e. Isaac's sacrifice interrupted by God's intervention), apparatuses of belief have, in different ways, attempted to neutralize and appease (auto-) sacrificial violence. In Judaism, it was done through the substitution of bloody sacrifice with the study of the Law. In Christianity, through the symbolical re-enactment of sacrifice in the offering of the Eucharist. In Islam, through the restricted prescription to sacrifice a sheep only once a year. In another context, Buddhism also sought to sublimate the sacrificial violence of the ancient Vedic religion. Jihadists radically oppose these attempts to restrict and sublimate the archaic violence of sacrifice. In committing sacrificial suicides, they return to a practice their religion had always forbidden.

PJCV: Your book does not address many issues of fundamentalist internet propaganda and networks financing jihadism. Is it because you would like to study these aspects in a future work or because, in your view, a philosophical approach to these questions seems less relevant?

Jacob Rogozinski: These questions seem less relevant to me. We are often too focused on the medium and tend to forget the message. Massive dissemination of executions and torture on the internet surely is Daesh's "trademark" but, with the exception of this medium, there is nothing new here. The spectacular exhibition of cruelty has always been the prerogative of political or religious sovereignty, as shown by the pyres of the Inquisition or by what Foucault called "the spectacle of the scaffold"17 ["L'élat des supplices"] under the monarchies of the classical age. This enables these apparatuses to exhibit their sovereign power and terrorize their subjects.

\footnotetext{
${ }_{17}$ Michel Foucault, Discipline and Punish (New York: Vintage Books, 1995), 32-69.
} 
PJCV: Unlike many French intellectuals, you do not mock statements such as "Je suis Charlie" or "You will not have my hate" ["Vous n'aurezpas ma haine"] ...

Jacob Rogozinski: "Je suis Charlie" did not necessarily mean a support of the libertarian and anticlerical style of this newspaper, a style which is typically French and often misunderstood abroad. Anyway, it is wrong to see any kind of contempt or hatred against Muslims in this statement which, above all, was the expression of our solidarity with all the victims of jihadist terror, whoever they may be. During the big demonstration of January 2015, some placards claimed: "I am Charlie, I am Jewish, I am policeman, I am Muslim ...”. I am very attached to the other statement: "You will not have my hate." This is the title of a beautiful book by Antoine Leiris, ${ }^{18}$ whose wife was murdered by jihadists at the Bataclan in November 2015. This statement teaches us not to respond to hatred by hatred -- that is, not imitate those who consider us as "absolute enemies" who need extermination. I do think that there is no "good use" of hate - because hatred only calls for hatred: when we respond to terror with a mimetic counter-terror, we risk becoming involved in an unending conflict. I would however like to clarify that to renounce hatred does not equal renouncing resistance. Those who hate us and wish to annihilate us must be fought without hatred. In this fight against jihadism, our best allies are the Muslims themselves, all those Muslims who refuse this deadly fanaticism which disfigures their religion.

\section{Interview conducted by Andreas Wilmes \\ Translated by Sandra-Lia Roşu \& Andreas Wilmes}

\section{References}

Assmann, Jan. Of God and Gods: Egypt, Israel and the Rise of Monotheism. Madison: University of Wisconsin Press, 2008.

Badiou, Alain. "Philosophy and the 'war against terrorism". In Infinite Thought, 141-163.

New York: Continuum, 2004.

Baudrillard, Jean. The Spirit of Terrorism. London: Verso, 2002.

Chantre, Benoît. "Terrorism and Democracy". The Philosophical Journal of Conflict and Violence $1 / 2$ (2017).

Derrida, Jacques. Acts of Religion. New York: Routledge, 2002.

Derrida, Jacques. The Gift of Death \& Literature in Secret. Chicago: University of Chicago Press, 2008.

Foucault, Michel. Power, Truth, Strategy. Sidney University: Feral Publications, 1979.

Foucault, Michel. Discipline and Punish. New York: Vintage Books, 1995.

Leiris, Antoine. You Will Not Have My Hate. London: Penguin Books, 2017.

Rogozinski, Jacob. The Ego and the Flesh. Translated by Robert Vallier. Palo Alto: Stanford University Press, 2010.

Rogozinski, Jacob. Ils m'ont haï sans raison : de la chasse aux sorcières à la Terreur. Paris: Éditions du Cerf, 2015.

\footnotetext{
18 Antoine Leiris, You Will Not Have My Hate (London: Penguin Books, 2017).
} 
Rogozinski, Jacob. «Le philosophe et le djihadiste ». Le Monde (February 20, 2015).

http:/ /www.lemonde.fr/idees/article/2015/02/20/le-philosophe-et-le-

djihadiste_4580674_3232.html (accessed October 5, 2017).

Rogozinski, Jacob. Djihadisme: Le Retour du Sacrifice. Paris : Desclée de Brouwer, 2017.

Žižek, Slavoj. Against the Double Blackmail. London: Penguin Books, 2016.

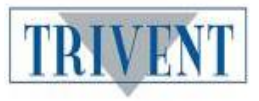

The PJCV Journal is published by Trivent Publishing. 